\title{
Raynaud's phenomenon in paediatric age
}

\author{
Ana Sofia Esteireiro ํㅜ, Anabela Bicho
}

Paediatrics Department, Hospital de Caldas da Rainha, Centro Hospitalar do Oeste, Caldas da Rainha, Portugal

\section{Correspondence to Dr Ana Sofia Esteireiro; esteireira@gmail.com}

Accepted 8 January 2020

\section{DESCRIPTION}

A 9-year-old female patient, with irrelevant personal and family history, was brought to the paediatrician's office because of vasospastic phenomena in hands and feet, bilateral and symmetrical, with 6 months of progress (figure 1). They usually last from 10 to $15 \mathrm{~min}$ with spontaneous resolution. Phenomena occurs once or twice a week, sometimes fortnightly and are triggered by cold, not by stress or pain. She denied systemic symptoms (asthenia, arthralgias, myalgias, fever, weight loss and so on). The examination showed acrocyanosis and sweating in hands and feet. No oedema, arthritis, fever or other changes. Modified Rodnan total skin thickness score was zero. Laboratory investigation showed positive rheumatoid factor, antinuclear antibodies (ANA) and anticentromere antibodies. Nailfold capillaroscopy revealed heterogeneous capillaries, observing niches of fine capillaries alternating with areas of rarefaction (ischaemia) with megacapilars and giant capillaries, with spontaneous rupture and periungual haemorrhage (figure 2). The findings are compatible with secondary Raynaud's phenomenon (RP), with active scleroderma pattern. The two dimensional and M-mode echocardiogram showed no signs of pulmonary arterial hypertension. The chest radiography and the lung function tests did not reveal any changes. Pulmonary CT scan was not performed. The child was referred for ophthalmology (no alterations) and rheumatology. She started treatment with nifedipine and nitroglycerin in SOS on colder days. She continues to be followed in rheumatology consultation every 4 months or earlier if new symptoms or intercurrences appear because of eventual scleroderma (score 8 in 2013 American College of Rheumatology - European League Against Rheumatism (ACR-EULAR) classification criteria). ${ }^{1-3}$

RP is caused by episodic spasm of the small arteries and arterioles of the fingers, in more severe cases it may also affect the nose, ears or tongue. ${ }^{4-9}$ It is triggered by several stimuli including exposure to

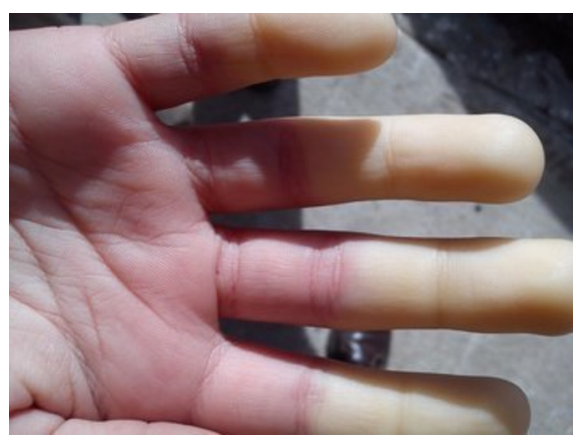

Figure 1 Raynaud's phenomenon.

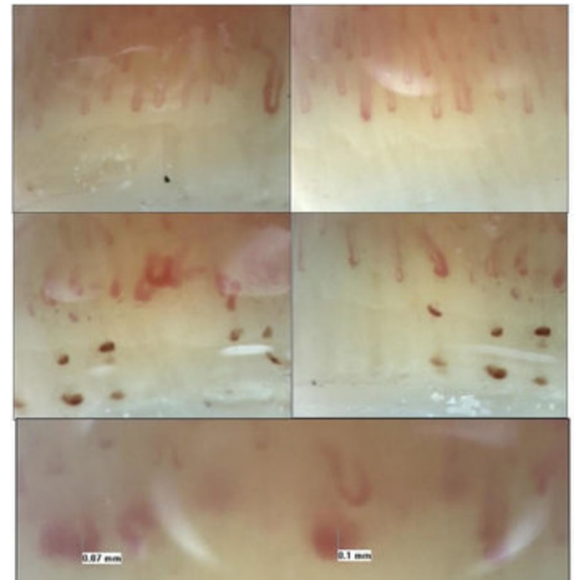

Figure 2 Videocapilaroscopy images.

cold or a stressful event. ${ }^{1-8}$ The afflicted area goes through a three-colour variation, from white, to purple and red (some cases only two colours). ${ }^{4-68-10}$ Its prevalence in paediatric age is unknown, but it is believed to be a rare and predominantly female entity, with most cases described in children aged 12-15 years. 681011

According to the aetiology, RP can be primary/ idiopathic ( $80 \%$ of cases) if symptoms occur in the absence of any associated disorder. Secondary $\mathrm{RP}$ is attributed to an underlying condition, most commonly connective tissue diseases including systemic lupus erythematosus or systemic scleroderma and so on. ${ }^{4-8}$

Diagnosis can be made using clinical history, physical observation, laboratorial and imaging studies. ${ }^{19-11}$ ANA's positivity and changes in capillary bed are suggestive of secondary RP. ${ }^{1} 5$ 10-12 Differential diagnosis includes: excessive cold sensitivity, external compression of blood vessels, peripheral neuropathy, complex regional pain syndrome, occlusive vascular disease, acrocyanosis, erythromelalgia and acute idiopathic blue

\section{Learning points}

Raynaud's phenomenon (RP) is a rare entity in paediatric age, and every patient should be carefully evaluated to distinguish primary from the secondary RP.

- In patients with symptoms or signs suggestive of systemic disease, laboratory tests should include antinuclear antibodies and other specific autoantibodies (like anticentromere), depending on the suspected underlying disease.

- Most cases are primary RP and the treatment is supportive. 
finger. ${ }^{48}$ Pharmaceutical agents including beta-blockers, cisplatin and bleomycin can also cause RP. ${ }^{5}$ Treatment includes patient education and eviction of stimulators. ${ }^{4589}$ In the secondary $\mathrm{RP}$ cases or with intense symptomatology, pharmacological therapy is recommended (may include calcium antagonists, alfablockers, nitrates, prostaglandins, selective serotonin receptor antagonists, selective serotonin reuptake inhibitors, endothelin receptors antagonists, ACE, pentoxifylline and acetylsalicylic acid). ${ }^{459}$ Surgery is reserved for cases resistant to pharmacological treatment. ${ }^{8}$

Contributors ASE: drafting the work. AB: revising it critically for important intellectual content. Both author's have been involved in the patient's care.

Funding The authors have not declared a specific grant for this research from any funding agency in the public, commercial or not-for-profit sectors.

Competing interests None declared.

Patient consent for publication Parental/guardian consent obtained.

Provenance and peer review Not commissioned; externally peer reviewed.

ORCID iD

Ana Sofia Esteireiro http://orcid.org/0000-0003-1603-0602

\section{REFERENCES}

1 Souza EJdoRe, Kayser C. Capilaroscopia periungueal: relevância para a prática reumatológica. Rev Bras Reumatol 2015:55:264-71.10.1016/j.rbr.2014.09.003

2 Wigley FM. Treatment of Raynaud phenomenon: Initial management [Internet]: UpToDate, 2019. Available: https://www.uptodate.com/contents/treatment-ofraynaud-phenomenon-initial-management [Accessed 05 Nov 2019].

3 Pain CE, Constantin T, Toplak N, et al. Raynaud's syndrome in children: systematic review and development of recommendations for assessment and monitoring. Clin Exp Rheumatol 2016;100:200-6.

4 Wigley FM. Clinical manifestations and diagnosis of Raynaud phenomenon [Internet]: UpToDate, 2019. Available: https://www.uptodate.com/contents/clinicalmanifestations-and-diagnosis-of-raynaud-phenomenon [Accessed 05 Nov 2019].

5 Lackey AE, Calvo V, Greidinger E. Pediatric Raynaud phenomenon workup and treatment: a case report. Florida Chapter of the American Academy of Pediatrics 2019;38:22-5

6 Wigley FM. Pathogenesis of the Raynaud phenomenon [Internet]: UpToDate, 2019. Available: https://www.uptodate.com/contents/pathogenesis-of-the-raynaudphenomenon [Accessed 05 Nov 2019].

7 Ortega Vicente E, Garrido Redondo M, Vicente EO. Fenómeno de Raynaud en pediatría. Reumatología Clínica 2016;12:342-4.

8 Zaragozano JF, Martínez GR, López JLO, et al. Acta Pediatr Esp 2009;67:297-300.

9 Pascual EG, Rychen GE, España AR, et al. Fenómeno de Raynaud en La infancia: Revisión Y control evolutivo de ocho casos. An Esp Pediatyr 1998;48:603-7.

10 Tavares M, Novo A, Sousa H, et al. Raynaud's phenomenon in pediatric age. Pediatr Rheumatol 2011:9:P234.

11 Nigrovic PA, Fuhlbrigge RC, Sundel RP. Raynaud's phenomenon in children: a retrospective review of 123 patients. Pediatrics 2003;111:715-21.

12 Piotto DGP, Len CA, Hilário MOE, et al. Capilaroscopia periungueal em crianças E adolescentes com doenças reumáticas. Rev Bras Reumatol 2012;52:727-32.

Copyright 2020 BMJ Publishing Group. All rights reserved. For permission to reuse any of this content visit

https://www.bmj.com/company/products-services/rights-and-licensing/permissions/

BMJ Case Report Fellows may re-use this article for personal use and teaching without any further permission.

Become a Fellow of BMJ Case Reports today and you can:

- Submit as many cases as you like

- Enjoy fast sympathetic peer review and rapid publication of accepted articles

- Access all the published articles

Re-use any of the published material for personal use and teaching without further permission

\section{Customer Service}

If you have any further queries about your subscription, please contact our customer services team on +44 (0) 2071111105 or via email at support@bmj.com.

Visit casereports.bmj.com for more articles like this and to become a Fellow 